\title{
Formula One racing and the end of tobacco sponsorship: half pregnant at $350 \mathrm{kph}$ ?
}

\section{S Chapman}

Formula One racing is one of the most watched events in the world, providing its main sponsor, the tobacco industry, with unparalleled exposure for its product

A friend recently told me about an incident when travelling in Brazil. A full plane waited on the tarmac for a seemingly interminable period as the flight attendants breathlessly announced that a VIP would be joining the flight soon ... ."we apologise for the delay". As the clock ticked and crossword puzzles were completed, passengers speculated on their imminent company. The President? The Pope? Koffi Annan? The mystery passenger was long retired Formula One icon Emerson Fittipaldi, like his deceased Brazilian compatriot Ayrton Senna, little short of a cultural divinity in Latin America.

During the 2001 Formula One (FI) Grand Prix in Melbourne, race marshall Graham Beveridge was tragically killed by a wheel flung from Jacques Villeneuve's disintegrating car. ${ }^{1} \quad$ A full coroner's inquest was held, followed by a review by motor racing's governing body Federation Internationale De L'automobile (FIA). One death was deemed worthy of a full investigation involving an international review team, front page reportage, and endless speculation about whether the
2002 race would be safe for spectators and officials. But what of the millions of deaths that will occur among smokers around the world across the next 30 years who will be exposed to a different sort of motor racing hazard? Yet again, ${ }^{2}$ it is worth recalling Stalin's axiom that a single death is a tragedy, but a million deaths are a mere statistic.

Grand Prix motor racing is the most watched event after the Olympics and the soccer World Cup, with each race broadcast to a potential viewing audience of 350 million. Its major sponsors over the last 20 years have been tobacco companies. As Dewhirst and Hunter describe in this issue, ${ }^{3}$ in 2001 the three leading Fl tobacco sponsors pumped some US\$753.5 million into the Grand Prix because they know it works wonders for their bottom line. It keeps brand names in front of a stratospheric number of people and powerfully distracts from all that regrettable stuff about smoking causing cancer. It builds a global constituency of craven politicians, all slavering to get and retain grand prix events in their cities. And above all it gives tobacco companies a

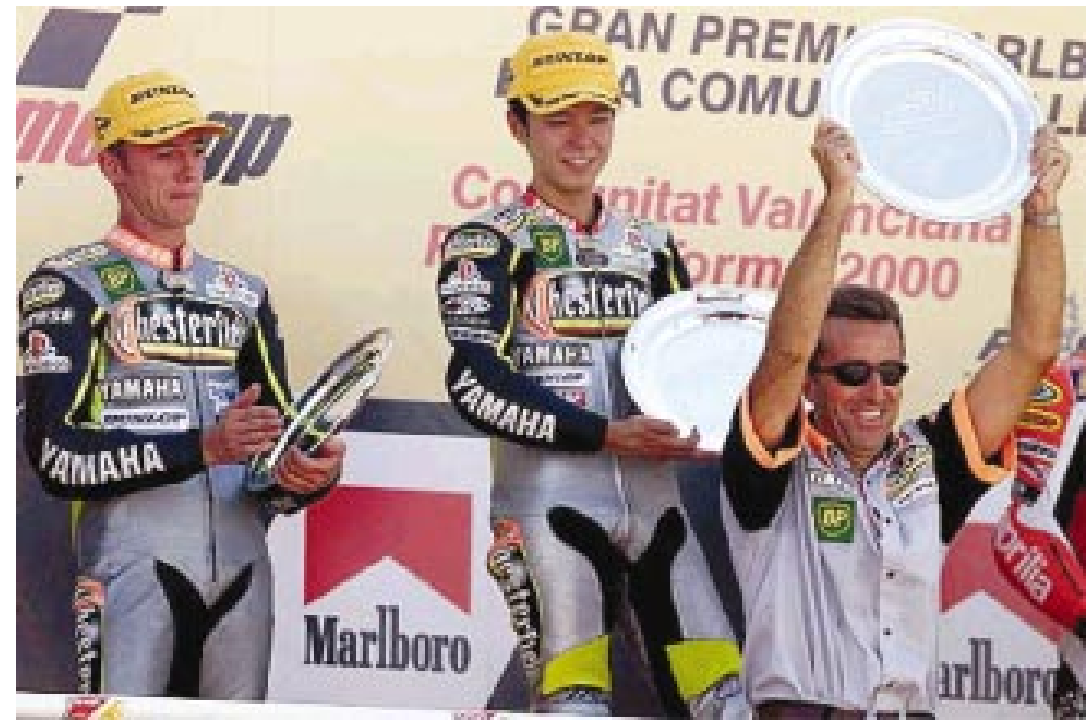

Figure 1 The Japanese Yamaha motor cycle team, emblazoned with logos from its various sponsors, including PlayStation and Chesterfield. stage to imply that they are exciting, respectable, and welcome to take their place in civilised company.

"Tobacco sponsorship is today's leading vector for the spread of lung cancer and other tobacco caused disease"

But as surely as mosquitoes spread malaria, tobacco sponsorship is today's leading vector for the spread of lung cancer and other tobacco caused disease. The World Health Organization puts the figure at over four million who die each year from tobacco caused disease, increasingly in less developed nations. While the racing fraternity routinely participate in road safety campaigns ${ }^{4}$ in recognition of their massive influence with the young who are over represented in road death statistics, promoting smoking to the same adoring fans seems to trouble few of them.

For industry apologists who snort "Who ever took up smoking after seeing the word 'Marlboro' painted on a car or a Lucky Strike billboard?", "It's only directed at adult smokers. Tobacco companies don't want kids to smoke", one need only consider the Japanese Yamaha motor cycle team which is sponsored by PlayStation, the child's electronic game, as well as by Chesterfield, the "adult's" cigarette (fig 1). Presumably some mysterious process lets children absorb PlayStation advertising on a rider's left sleeve but makes them oblivious to the tobacco logos emblazoned across his chest. Tobacco advertising —along with junk food advertisers whistling tunes in childrens' viewing periods-are the only forms of advertising where we have the sad spectacle of its defenders trying to claim that it doesn't work.

In Australia, tobacco sponsorship was banned in 1995. However, the law left a loophole to allow a handful exemptions for elite international sports like Grand Prix and Indycar. This was "half pregnant" politics at its worst. The arguments that sustained the decision to ban Benson and Hedges sponsorship of cricket in Australia, Winfield's of the rugby league, and Peter Jackson's of local motor racing of course apply exactly to the Grand Prix, but with bells on.

Max Mosley, president of Formula One's world governing body, announced last November with Gro Harlem Brundtland, director general of WHO, that the Grand Prix would end all tobacco sponsoring at the end of the 2006 season. ${ }^{5}$ The former Australian health minister Michael Wooldridge had acted to close the loophole by amending the Act in 2000 in an action that may have caused the dominoes to start tumbling for FIA. Earlier this year an ever pragmatic Mosley had this to say on the subject: 
"But there is a general worldwide movement against tobacco and although I don't think it will actually make any difference to the number of people who smoke, or any of those issues-that's my personal view-the fact remains that the trend is against. If you were to allow Formula 1 to go on with tobacco advertising, two things would happen. You would gradually restrict the number of countries in which you can have a Grand Prix, and secondly, you would tend to push Formula 1 into a kind of side road of sponsorship and you might well find that general sports sponsorship overtook you. You were stuck there with tobacco, completely in their hands, and even though the money was going up everywhere else, you couldn't introduce any of that into Formula 1 because none of them would come in because you've got tobacco. So you have a double risk: cutting down the countries, losing out on sponsorship. It seemed to me that the right course was to try to get out of tobacco and bring Formula 1 back into the mainstream of sports sponsorship." ${ }^{6}$

Whenever tobacco sponsorship has been threatened in the past, a sordid cavalcade of sponsorship fattened sports administrators and sound bite fed sportsmen have threatened the end of the world. As we all now know, Marlboro's ignominious exit from the Australian Open Tennis reduced that event to little more than a suburban tennis match.
Since Benson \& Hedges left the cricket, the Australian team has barely won a game.* Presumably, the five years grace for tobacco in the grand prix is born of the same nonsense.

Five years grace is supposed to make everyone feel that justice has finally been done. But imagine if after last year's trackside death in Melbourne grand prix officials had retorted "well, we acknowledge that safety problems exist at the track, but let's not go overboard here ...we're announcing that we will fix these problem in five years." The moral revulsion would be palpable. If Mosley and FIA know it is wrong and socially unacceptable to abet tobacco companies by providing them one of the world's largest stages to do their dirty work, it is wrong now, wrong next race, and wrong all next year. It is not simply wrong five years from now.

Society expects those who have done wrong to do five things: admit they did it; say they're sorry; try to make good the damage done; promise never to do it again; and do a penance or public humiliation, symbolising that they accept they

*For those readers from non-cricketing nations, for years Australia has been the undisputed world champion in this sport, regularly humbling - some might say disgracing - teams from nations with far larger populations, such as England and South Africa. have done wrong. Is it unimaginable that FIA officials and the leading drivers who have done more than any other individuals on earth to promote smoking, might think about how they could meaningfully do these things?

Tobacco Control 2002;11:87-88

\section{Author's affiliation}

Correspondence to: Professor Simon Chapman, Department of Public Health and Community Medicine, Edward Ford Building A27, University of Sydney, NSW 2006, Australia: simonc@pub.health.usyd.edu.au

\section{REFERENCES}

1 Highfield J. Inquest into fatal Grand Prix accident. The World Today (ABC radio Australia). 3 December 2001. URL: http://www.abc.net.au/worldtoday/ s431452.htm

2 Shatenstein S, Chapman S. The banality of tobacco deaths. Tobacco Control 2002;11:1-2.

3 Dewhirst T, Hunter A. Tobacco sponsorship of Formula One and CART auto racing: tobaccon brand exposure and enhanced symbolic imagery through co-sponsor's third party advertising. Tobacco Control 2002;11:146-150.

4 Federation Internationale De L'automobile. Ten seconds that can save your life. URL: http://www.fia.com/tourisme/ AutoMotive/automotive8a/10-secondes/ 10_secondes.html

5 Anon. Fl to ban cigarette ads. CNN. 22 November 2001. URL: http:// europe.cnn.com/2001/WORLD/europe/11/ 22/fia.tobacco/

6 Forumla 1.Com Max Mosley interview. 16 February 2002. URL: http:// www.formula 1.com/news/headlines02/02/ s8479. html

\section{ABOUT THE COVER}

\section{Tobacco advertising in cyberspace}

The rocket scientist on the cover was used by Brown \& Williamson in 1958 to convey the impression that intelligent and thoughtful people were smokers, and smokers of their Viceroy brand, of course.

This campaign, although it ran for only a year or so, had many other finely executed and beautiful variants featuring professionals who each "thinks for himself" and "knows the difference between fact and fancy": an electrical engineer, an atomic physicist, a newspaper editor, an astronomer, a TV journalist, an anthropologist, an automobile designer, and even a football coach. Also evident is the visible smoke, now an anachronism. This interesting campaign and its richness of variations is just a glimpse of the enormous collection of tobacco advertising assembled by Rick Pollay and now available on the web.

Dr Richard W (Rick) Pollay, a business school Professor of Marketing at the University of British Columbia (Vancouver), was researching the history of advertising, among other topics, when invited to do a content analysis study of cigarette advertising from the 1940s and 50s for the path breaking Cipollone case (New Jersey 1987). The vigour and hostility of the tobacco industry's reaction to his marketing expertise and evidence, and the multidisciplinary nature of tobacco policy issues, provoked him to continue research in this area and to investigate the history of cigarette advertising practices in depth. Over the years this has led to over 100 research work products, including many refereed publications in both his own areas (advertising and marketing) and in tobacco control. He has contributed to multiple Surgeon General's reports - those on children, minorities, and women. He has also been asked to share his knowledge with juries in numerous tobacco trials in both the USA and Canada. This expert witnessing granted him early access to volumes of corporate documents. This collection of advertising examples is a component part of the Tobacco Industry Promotion Series (TIPS) at the History of Advertising Archives where he is the curator. The TIPS holding is a much larger collection which also includes corporate documents, sundry artefacts such as candy cigarettes and tobacco toys, material on the industry's use of public relations, reels of tobacco TV ads, etc.

In April 1999, Dr Pollay donated approximately 8000 slides containing tobacco advertisements, tobacco industry issue ads, and anti-smoking ads to the Roswell Park Cancer Institute, with another 2000 donated in 2001. Under the leadership of Dr Michael Cummings, a team of professional librarians has created a catalogue of most of these 10000 images. Roswell Park will continue to seek new and novel ways to expand this resource through collaboration and collection, including new material compiled by Dr Pollay, by Roswell Park staff, and by other potential collaborators. Please note, however, the contents of this collection are intended for educational, academic, and non-commercial use only. These many US ads can be accessed at the web site: http://roswell.tobaccodocuments.org/pollay/dirdet.cfm 